\title{
Worlds Pictured in Contemporary Art: Planes and Connectivities
}

\author{
Terry Smith
}

It is difficult to imagine a theme more relevant to contemporary concerns than that of this conference. ${ }^{1}$ The imagining of worlds within the World is a topic that has concerned me for some time, to the extent of nominating it in recent publications as one that is at the core of contemporary art, as it is of current being-in-the-world, and thus definitive of our contemporaneity. For example, I conclude a recent article, 'The State of Art History: Contemporary Art', with the following remarks:

Placemaking, world picturing and connectivity are the most common concerns of artists these days because they are the substance of contemporary being. Increasingly, they override residual distinctions based on style, mode, medium and ideology. They are present in all art that is truly contemporary. Distinguishing, precisely, this presence in each artwork is the most important challenge to an art criticism that would be adequate to the demands of contemporaneity. Tracing the currency of each artwork within the larger forces that are shaping this present is the task of contemporary art history. ${ }^{2}$

These are, I know, bold claims, but I am encouraged in pursuing them because I know them to be accurate pointers to the main (but of course not the only) concerns of contemporary artists. They are also a straightforward-if rather summary-description of the enterprise of many art critics, historians and theorists of visual cultures working throughout the world today.

The second issue of the journal World Art is devoted to contemporary art. I have contributed an essay that attempts to answer the question: Can we say that contemporary art is - perhaps for the first time in history-truly an art of the world? I argue along the following lines:

As biennales have for decades attested, art now comes from the whole world, from a growing accumulation of art-producing localities that no longer depend on the approval of a metropolitan centre and are, to an unprecedented degree, connected to each other in a multiplicity

\footnotetext{
1 'The World and World-Making in Art' Conference held at The Australian National University, 11-13 August 2011. My thanks to Caroline Turner, Michelle Antoinette and Zara Stanhope.

2 Smith, T. 2010, 'The State of Art History: Contemporary Art', Art Bulletin, vol. XCII, no. 4, p. 380.
} 
of ways, not least regionally and globally. Geopolitical change has shifted the world picture from presumptions about the inevitability of modernisation and the universality of EuroAmerican values to recognition of the coexistence of difference, of disjunctive diversity, as characteristic of our contemporary condition. Contemporary life draws increasing numbers of artists to imagine the world-here understood as comprising a number of contemporaneous 'natures': the natural world, built environments ('second nature'), virtual space ('third nature'), and lived interiority ('human nature') - as a highly differentiated yet inevitably connected whole. In this sense, from what we might call a planetary perspective, contemporary art may be becoming an art for the world - for the world as it is now, and as it might be. ${ }^{3}$

My essay is accompanied by an insightful commentary by Marsha Meskimmon that adds much depth to my raw intuitions about the affective dimensions of the kinds of coeval ethics called for in contemporary conditions: the world 'as it might be'. Ian McLean has also contributed an important essay that ties, in his unique way, the world to Australian perceptions of it.

Two ideas from within the passage I have just quoted attract attention as being key topics of relevance to this conference. For over 50 years now, a world historical shift from EuroAmerican hegemony to a declining dominance within an increasingly differentiated world geopolitical and economic order has been underway-recently, at an accelerating pace. It has found expression in art, I suggest, as a shift from various kinds of practices oriented for, against or at oblique angles to modernisation (not all of which are modernist) to practices that arise out of contemporary conditions. I will return in my conclusion to some implications for art historical writing of this world-wide shifting from modern to contemporary art.

\section{Worlds-Within-The-World}

I want to focus the main part of my remarks on the kinds of worlds that are envisaged in the passage I just quoted. I will not develop the metaphor of worlds as 'natures'. I am of course alluding to world picturing as envisaged by Karl Marx and Frederick Engels in the Communist Manifesto of 1848, the quintessential description of the forces at play in the then modernising world. Rather, I will put before you a description that I believe is more suitable to our current, post-1989 circumstances: that of contemporaneous worlds linked by a mix of direct determination, contingency, planetary transformation, and also, paradoxically, by particular kinds of non-contemporaneity.

3 Smith, T. 2011, 'Currents Of World-Making In Contemporary Art,' World Art, no. 2, pp. 20-21. 


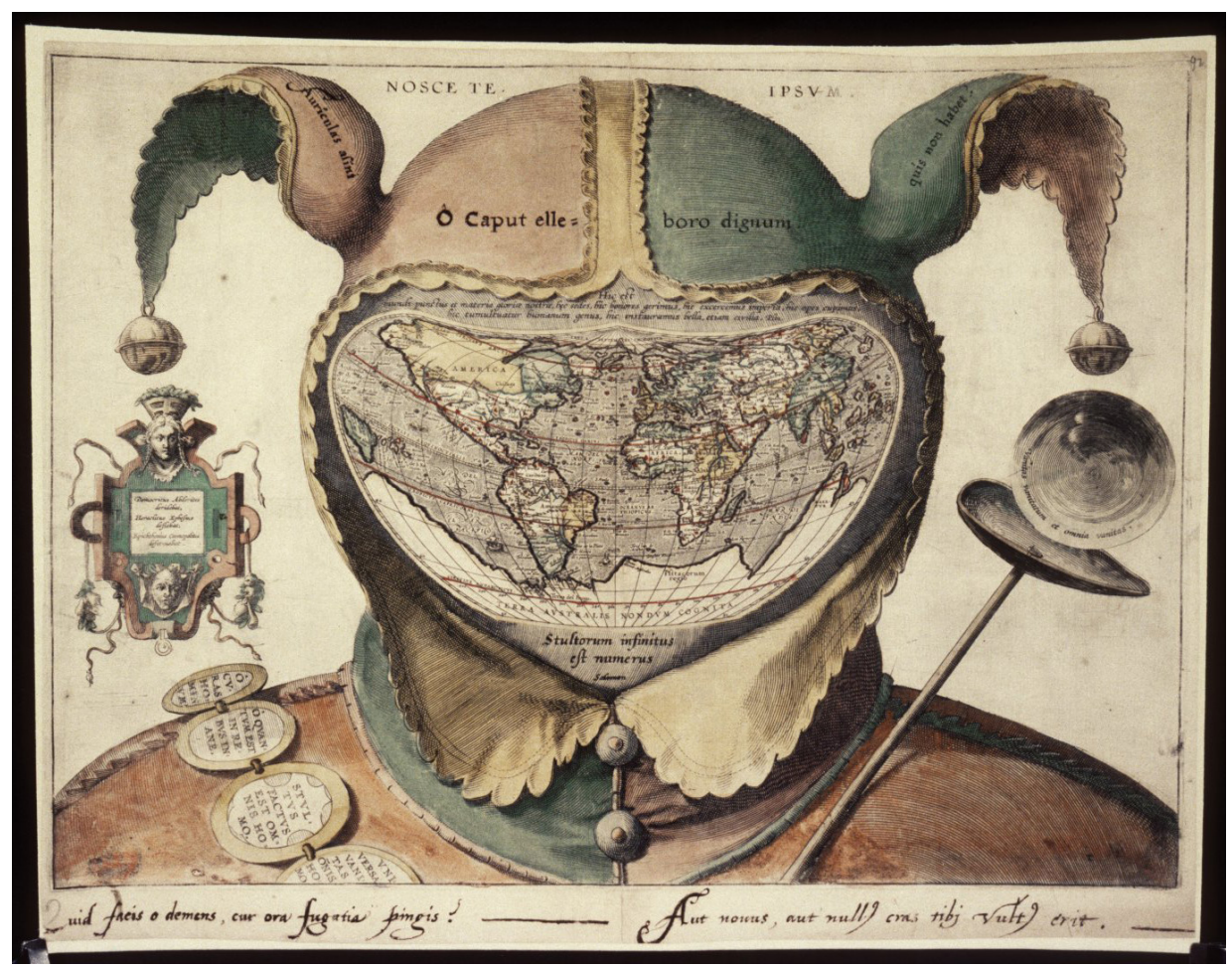

Anon., c. 1590, World Map (Fool's Cap).

Bodleian Library, University of Oxford, Bodleian Map Room, Douce Portfolio 142 [92]

There is, I acknowledge, a degree of foolishness in attempting such general descriptions. This is especially true at times of world disturbance, a truth we see pictured in the famous image of the World Map (Fool's Cap), c. 1590.

The most recent mapping of the continents (close to those published by Ortelius in the 1580s) is framed by a court jester's outfit, and laced with mottoes of biblical and classical origin, all of them warning against the vanity of presuming to know too much. The legend in the left panel reads: 'Democritus of Abdera laughed at [the world], Heraclitus of Ephesus wept over it, Epichtonius Cosmopolites portrayed it'. Across the cap's brow, the inscription translates as 'O head, worthy of a dose of hellebore'. The Latin quotation just above the map is from Pliny the Elder: 'For in the whole universe the earth is nothing else and this is the substance of our glory, this is its habitation, here it is that we fill positions of power and covet wealth, and throw mankind into an uproar, and launch wars, even civil ones'. The reason for this chaos is explained in the quotation below the map, from Ecclesiastes: 'The number of fools is infinite'. The jester's staff at right also cites this book: 'Vanity of vanities, all is vanity'. Inscribed on the badges adorning the shoulder belt are sayings to the effect: 
'Oh, the worries of the world; oh, how much triviality is there in the world', 'Everyone is without sense', and 'All things are vanity: every man living'. The most important motto is the one that presides above them all, the Latin version of the Greek dictum 'Know thyself'. Framing scientific truths as 'fancies' was, of course, an essential strategy at times of Inquisition. In 1590 we were 40 years into the Roman Inquisition, and 40 years before the trial of Galileo Galiliei.

How does the challenge of world picturing resonate in contemporary art? Let me begin in an equally specific way, with these words of Adelaide artist Fiona Hall: 'I live in the late twentieth century and this is my subject matter and what influences my work. I'm informed everyday by switching on the evening news, by looking at the newspaper, by reading current art magazines, by observing events around me - I think my work reflects this and it therefore has a contemporary presence. I certainly hope it does'. ${ }^{5}$ Julie Ewington identifies Hall's Gulf War ceramics of 1991 as a turning point in the artist's efforts to discern the impact of distant, 'world events' on the closeness that constitutes our sense of place. ${ }^{6}$ Since then, Hall has consistently attempted to show how global forces shape locality by tracking their presence in everyday objects, which she then assembles into evocative installations. Her Biodata series includes works such as Medicine bundle for the non-born child (1994): a delicate-looking baby's layette knitted from strips made from Coca-Cola cans, with the addition of a six-pack of cans with rubber teats. The transformation of coca leaves and nuts as medicinal plants in South America into the ubiquitous symbol of commodity capitalism, which has become a dangerously unhealthy addiction for millions, is amusingly yet sharply suggested.

\footnotetext{
4 Versions held in the Bodleian Library at University of Oxford and the Royal Geographic Society in London. Translations by Frank Jacobs on his Strange Maps site, post no. 480, viewed 20 February 2013, http://bigthink.com/ideas/24015

5 Fiona Hall cited in Pam, M. (ed.) 1989, Visual Instincts: Contemporary Australian Photography, Canberra, AGPS Press, p. 14.

6 Ewington, J. 2005, Fiona Hall, Annandale, Piper Press, p. 125. See also O'Brien, G., Savage, P. and Webb, V. 2007, Fiona Hall Force Field, Sydney, Museum of Contemporary Art.
} 


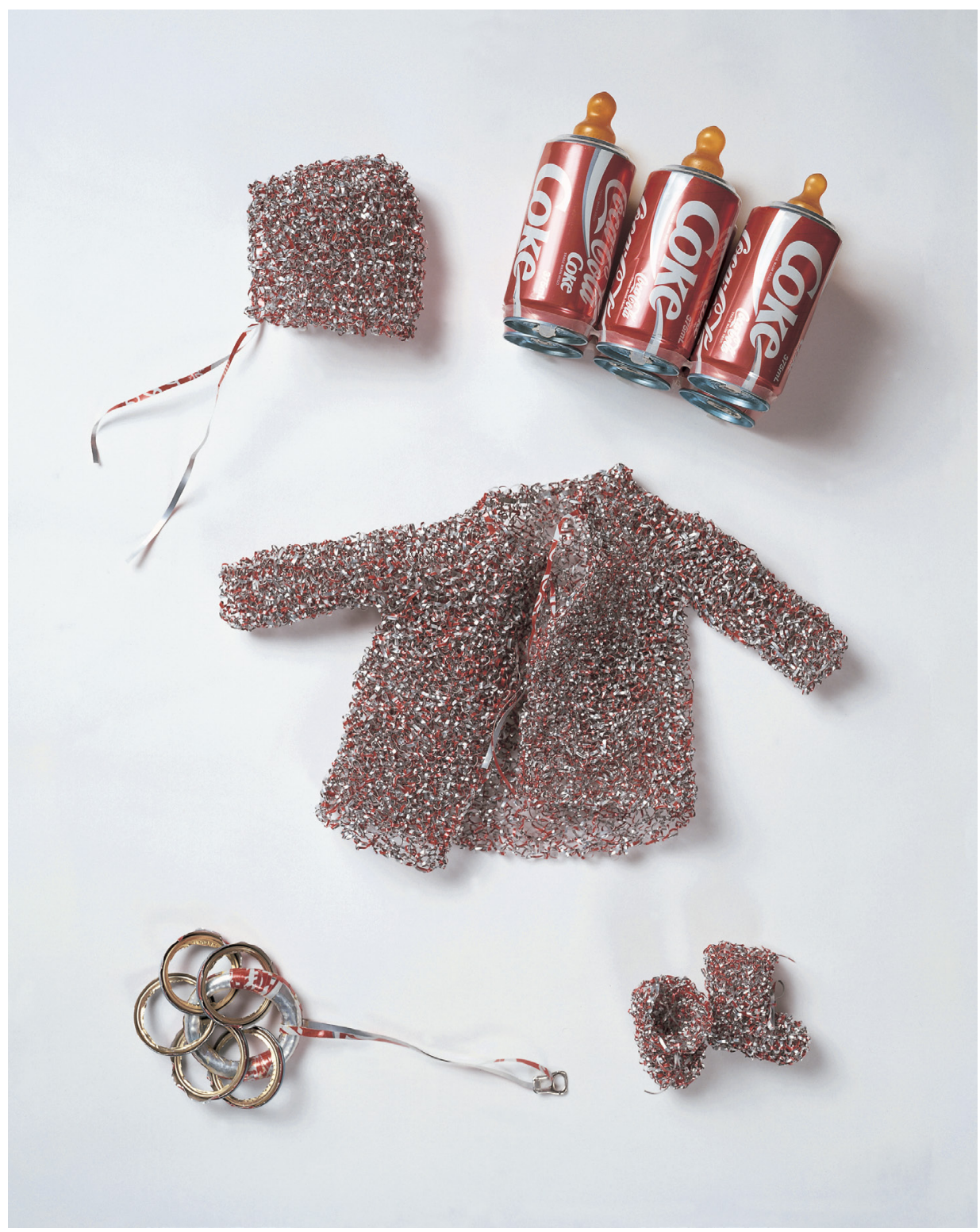

Fiona Hall, 1994, Medicine bundle for the non-born child, Biodata series, Collection Queensland Art Gallery, Brisbane, Aluminium, rubber and plastic, dimensions variable.

Courtesy the artist and Roslyn Oxley9 Gallery, Sydney 
At first glance, Hall's sculpture Incontinent (1997) might imply the gathering around a table of two individuals suffering from loosened bowels, but I read it as a subtle visualisation of some of the key connectivities operative in the world today. It is part of a suite of similar works from 1998-99-Drift Net, Fieldwork, White History, Dead in the Water and Cell Culture-in which quasi-anthropomorphic forms suggest body parts that have been subject to scientific examination, quasi-organic forms suggest plumbing fixtures or medical instruments, while animal parts merge into machinic elements. Much of this merging is conveyed by the choice of materials: PVC pipe, plastic, glass beads. The economic history of the use of these materials is grounded in cruel colonialism and vastly exploitative imperialism. White History places on one side of a Natural History Museum style vitrine a black orb, on the other a white metronome, and connects them visually through intricate piping. The black orb had appeared one year before in Incontinent, where it faced off across the Formica tabletop against a white, twisted pipe that culminated facedown in a plastic suction cap. The game, on the surface, is simple. On a plane spotted with holes, there are two players, one that rolls uncontrollably, the other that is fixed in place: two continents are symbolised, two civilisations perhaps, but they are shown as embodying two kinds of impotence. If the tabletop is the world that we can see clearly, the legs below show that the world is supported by a firm structure that has risen from beautifully turned natural wood, switched into metal piping, and holds up what is probably pulpboard laminated with marbleised plastic. The three ages of manufacture elegantly evoked. In between them, however, twists a parallel structure, more rhizomatic in character: random, over-elaborated plumbing fixtures, molded from Tupperware, and pierced with delicate designs representing the flora and fauna of the world's continents. Perforated like this, these pipes do not hold water. The incontinence of the continents. 


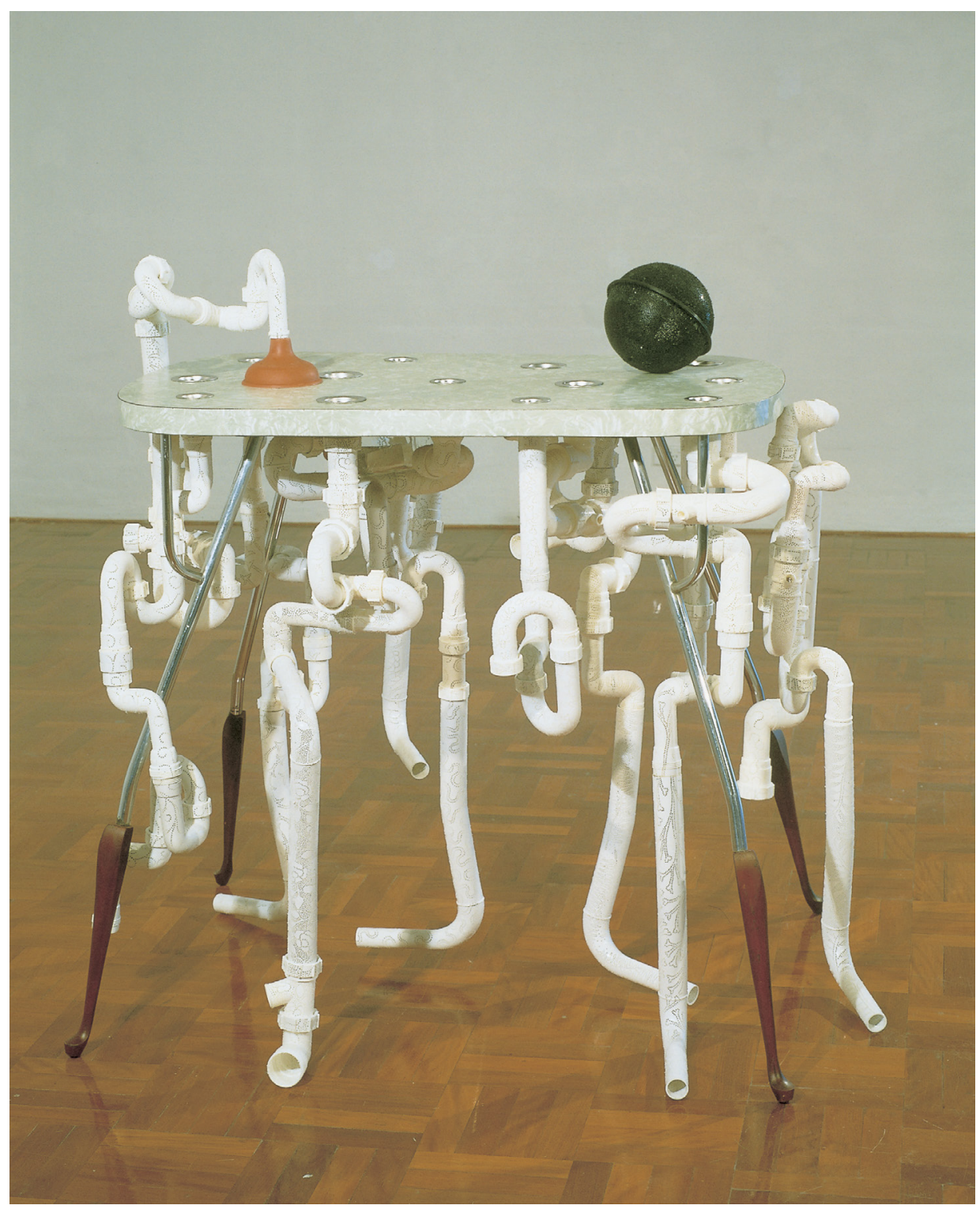

Fiona Hall, 1997, Incontinent, Collection Bendigo Art Gallery.

Courtesy the artist and Roslyn Oxley9 Gallery, Sydney 
In recent years Hall has sought ever more subtle ways of suggesting the complex connections that have shaped the contemporary world. Cash Crop (1998) displayed a variety of everyday and exotic plants carved in soap the botanical names for which were matched with terms from financial markets. Leaf Litter (1999-2003) is a series that connects the concentration of wealth in parts of the world with the distribution of plant species that has been crucial to that accumulation. Black and white images of plant species (taken from historic botanical illustrations) are painted in gouache on brightly coloured banknotes, each carefully chosen to suggest a historical or present relationship. As Ewington comments: 'This ambitious profusion is essential to the work: it embodies the almost unimaginable richness of the natural world, the breadth of human knowledge about plants and their properties, and the gross and abundant energies of commercial traffic, creating edgy dialogues between all three' ${ }^{7}$ Her works might be seen as artifacts of these dialogues: as examples of the kinds of thing that dialogic exchange between these forces and flows might be if they were, indeed, things. Small wonder that they seem such strange, impossible hybrids, and yet look like things that have always existed but have never been seen before.

\section{Spatial Layering, Temporal Contemporaneousness}

Like many other artists working today, Hall's work displays the physical conjunction of a number of different kinds of world: the intimate, personal sense of 'my world'; the close neighbourhood of the local; further worlds, increasingly distant beyond, until a sense of the World in general is reached; then the transitory, 'no-places' in between. Furthermore, this kind of art evokes the co-temporality of these worlds, their differential movement through time. Let me take this spatial idea of simultaneous worlds and marry it to the idea of these worlds sharing temporal contemporaneousness in an effort to envisage the structure of the world as we experience it today. Beginning spatially, we might imagine four planes, surfaces, fields, arenas, or domains that stand to each other as layers - 'orders' in an older parlance, or 'levels' in a more recent one. Let us call them 'worlds' in the sense of worlds-within-the-World.

WORLD/WORLDS: PLANES, LAYERS

Earth, planet, natural histories, evolution, information

Sentient interiority (human, animal, things? machinic?)

Societies, social relations, cultures, local economies, nation states

Geopolitics and economics, international arrangements, ngos, civilisations 
I have been inspired to this (tentative) proposal partly in reaction against the somewhat simplistic modeling recently advanced by theorists of globalisation and government such as Samuel P. Huntington and Joseph Nye Jr. ${ }^{8}$ Nye suggests that we envisage the distribution and play of power throughout the world as a chess game played on multiple boards at once, in which actors moving pieces on one board (say, the geopolitical) impact on another (say, the cultural). He urges that, if the United States is to retain its preeminence it must act in awareness of the effects of power across all relevant domains, and do in a planned way, within frameworks of conscious policy (thus his concept of 'soft power', avidly adopted as a tool of foreign policy by governments around the world today, not least the Chinese government). Being actually more concerned with coercive power, having forgotten their Foucault, and being unconcerned about climate change, both Nye and Huntington pay little attention to interiority and the planetary. But their models do have the virtue of highlighting the fact that we form perspectives on the world at large according to the forces in play within the world, or worlds, in which we mostly act, or most immediately need to act, and that we are often unaware, or unable to envisage, the nature of the relationships that connect them.

With these cautions in mind, let me complicate the diagram with some suggestions as to the kinds of relationship that are commonly held to connect these planes. I indicate only some of the most prominent forms that these relationships take, through the names that these relationships have attracted.

WORLD/WORLDS/WORLDING: PLANES \& RELATIONSHIPS

Earth, planet, natural histories, evolution, information

$<$ Indigeneity, ecology, virtuality $>$

Sentient interiority (human, animal, machinic? things?)

$<$ art, language, sexualities, belief, humanities, sciences, media>

Societies, social relations, local economies, nation states, cultures

$<$ diplomacy, war, criminality, cooperation $>$

Geopolitics and economics, international arrangements, ngos, civilisations

$<$ modernity, globalisation, globality, planetarity $>$

To 'complete' (to the degree that that is possible) my first, evidently tentative sketch of this world picture, I would posit that a host of actions, difficult to diagram, actually weave the connections, are the substance of relationships, within this model. Let us call them 'connectivities'. They include imagination, feeling, projection, identification, communication; producing, consuming, presuming; warring, surging, peace-making, reconciling, deterring, negotiating; searching, networking, flocking; and many others both shared and specific to

8 Huntington, S. P. 1997, The Clash of Civilizations and the Remaking of the World Order, New York, Simon and Shuster; Nye J. S. Jr, 2011, The Future of Power, Cambridge, Mass., PublicAffairs; and Nye J. S. Jr, 2004, Soft Power: The Means to Success in World Politics, Cambridge, Mass., PublicAffairs. 
particular practices. Imagine them as threads weaving through these layers and forms of connection, thus giving us a three-dimensional matrix. (I hope that the relevance of Fiona Hall's impossible hybrids is now clear.) Let us call this overall activity, this weaving of connectivities, 'world-making' or 'worlding'.

Please notice what we might call the rounding of the model, its return to itself, such that our taking of the Earth itself as the grounding matches, at world scale, a planetary consciousness rather than a globalising thirst for dominance and hegemony. (One ambition is to enable a conception of the world that does not begin from the image of the globe, or that of a map of continents, but of course includes them within a broader pictorial imagining of worlds-within-the-World that now stretches through more space and more time and in more differentiated ways that hitherto imaginable.) ${ }^{9}$

If something like this connective layering is the structure of our intersecting worlds, how might we understand it to have changed throughout time? ${ }^{10}$ I am incapable of imagining this across more than a few decades with any confidence (and even then with much trepidation), before succumbing to an unfounded hubris. But others, thank heavens, are less restrained. We can see in our cinemas today one such example: Terrence Malick film, The Tree of Life. For all of its obvious flaws, New Age over-reaching, and quasi-Creationist banalities, this is an extraordinary effort to imagine visually the world historical dynamic of something like the structure I have just sketched.

\section{Country and Connectivity}

One element lacking from Malick's world picture is Indigeneity. In this country, recently, we are learning to take indigenous perspectives less as obligatory additions to a broader but nonetheless Eurocentric perspective, more as something close to an equivalent, indeed preceding, starting point. For millennia, indigenous Australians have been depicting 'country' to themselves as part of ceremony and less formal spiritual observance. The 'masterpieces' of the contemporary Aboriginal art movement are complex, multilayered evocations of convergent 'dreaming lines' across vast actual and religious territory. Classic examples, to take two from the collection of the Art Gallery of New South Wales, range from Mawalan and Wanjuk Marika's Djan'kawu Creation Story (1959) to John Mawurndjul's Mardayin (2001), or, to take two from the collection of the

9 Just how difficult it is to move from this limited repertoire of models can be seen from recent surveys of modes of data visualisation. See, for example, Lima, M. 2011, Visual Complexity: Mapping Patterns of Information, New York, Princeton Architectural Press.

10 A comparable approach to these questions may be found in Christian, D. 2004, Maps of Time: An Introduction to Big History, Berkeley, University of California Press. On the history of conceptions of time, see Elias, N. 1992, Time: An Essay, Oxford, Oxford University Press and Christian, D. 2011, 'History and Time', 
National Gallery of Victoria, Napperby death spirit Dreaming, painted by Tim Leura Tjapaltjarri and Clifford Possum Tjapaltjarri in 1980, to Ngayarta Kujarra, painted in 2009 by a large group of artists from Punmu, Western Australia.

Connectivity may be understood less as a state of being connected in some fixed array, more as an ongoing process of seeking out the lineaments of connection, catching glimpses of them, allowing them to resonate, change, and inevitably loosen, only to seek them again. Something of this spirit informs the 2006 collaboration between Pura-lia Meenamatta, a poet from the Ben Lomond clan of the Cape Portland nation of North-East Tasmania who is also named Jim Everett, and Jonathan Kimberley, an eighth generation descendent of First Fleet convicts, a painter who lives and works between Hobart and Warmun, Western Australia. Their meenamatta lena narla puellakanny-Meenamatta Water Country Discussion took the form of an exchange between 13 of Pura-lia Meenamatta's poetic/prosodic reflections and ten of Kimberley's paintings. Puralia Meenamatta's poems range from evocative observations of creeks, rivers and rainwater at places in his country to speculations on water's centrality in global politics. 'Some call me water' begins:

$$
\begin{aligned}
& \text { some call me water } \\
& \text { nearly all need me } \\
& \text { i touch nearly everything } \\
& \text { connecting the inanimate } \\
& \text { with living things }
\end{aligned}
$$

whereas 'Europa' consists entirely of these lines:

$$
\begin{aligned}
& \text { colonies established post-colonialism } \\
& \text { which became neo-colonialism in the } \\
& \text { new nation of people exclusively } \\
& \text { under the controlling marketplace } \\
& \text { until all-life dies and neo-colonialism } \\
& \text { reaches its final regression } \\
& \text { in broken water dead. }{ }^{11}
\end{aligned}
$$

A student in Melbourne during the later 1980s, Jonathan Kimberley is of a generation of painters for whom the contemporary Aboriginal art movement was no longer a fascinating, from-the-deserts phenomenon, its future filled with as much uncertainty as hopefulness. Yet it had not quite achieved the diversity of output, continent-wide spread and depth of market that have made it, since 2000, a structural force at least as definitive of Australian art as the work of non-indigenous artists. During the 1990s interaction between the two kinds of 'Australian' art waxed and waned, often becoming intense, even volatile - especially when artists on both 'sides' used appropriative strategies.

11 Everett, J. and Kimberley, J. 2006, Pura-lia Meenamatta and meenamatta lena narla puellakanny: 
Exchanges between Michael Nelson Tjakamarra and Tim Johnson, and those between Gordon Bennett and Imants Tillers, are striking pairings among a wide variety. If they began as actions that sought to cross deep cultural divides, these encounters subsequently underwent complex transformations, only some of which can be properly understood as convergences. ${ }^{12}$

Kimberley and Pura-lia Meenamatta have inherited this history. Their approach, however, is post-appropriative. After graduating, Kimberley elected to live and work in remote communities, and was the founding manager of the Warmun Art Centre at Turkey Creek (1998-2000). In his paintings, echoes of some of the major Aboriginal artists may be seen (Michael Nelson's wild brushstrokes, Emily Kame Kngwarreye's lines), as may that of others (Jackson Pollock's thrown networks, Colin McCahon's textual admonitions), but these are faint. And they are way less important than his tipping and tilting the canvas to let lines of poured paint run in rivulets, randomly, all over the linen, or his picking out the shapes of natural growth, or his writing across the resultant surfaces the words that should be sung over them.
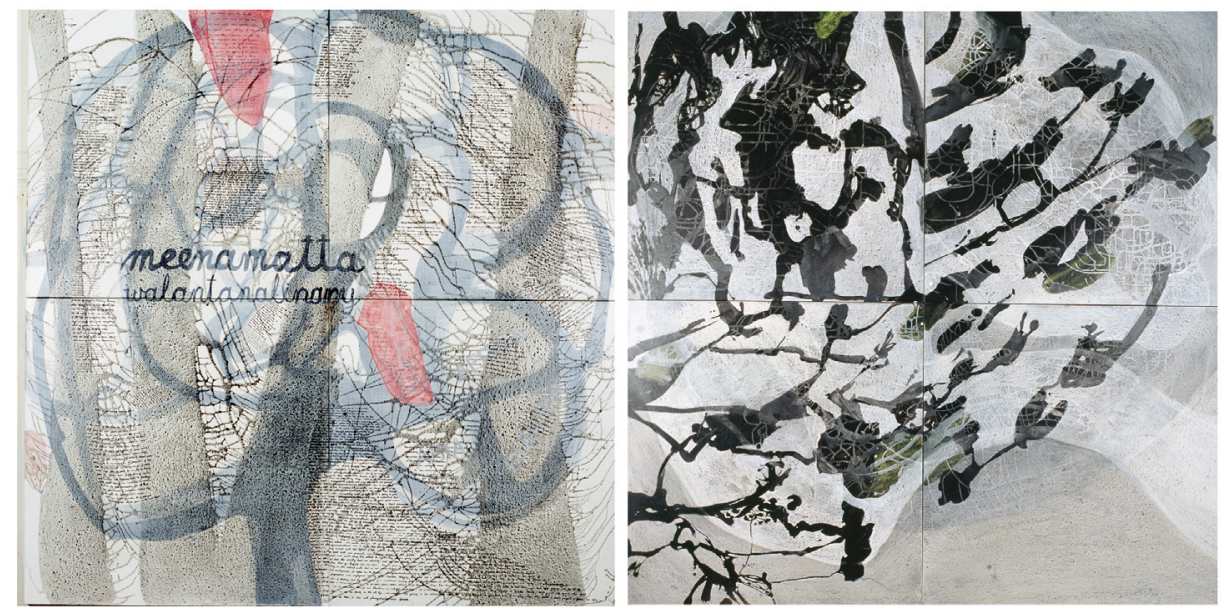

Pura-lia Meenamatta (Jim Everett) and Jonathan Kimberley, 2006, beyond the colonial construct: meenamatta map of unlandscape, and meenamatta water country, Synthetic polymer, charcoal, text and linen, diptych, each work 244 x $244 \mathrm{~cm}$.

Courtesy Bett Gallery, North Hobart

The core figure of beyond the colonial construct: meenamatta map of unlandscape (2006), a diagram, suggests at once a bush, a brain and a fish trap. It is a

12 Ian McLean has traced these in a number of his essays, notably McLean, I. 2010,'9 shots 5 stories: Imants Tillers and Indigenous Difference,' Art Monthly, no. 228, pp. 13-16 and ibid., no. 229, pp. 12-16. For some key original texts on the issue see McLean, I. (ed.), 2011, How Aborigines Invented the Idea of Contemporary Art, Brisbane, Institute of Modern Art, and Sydney, Power Publications, p. $263 \mathrm{ff}$. 
free-standing shape, but also a watery stain across a surface, one that leaves dissolving charcoal in its wake. It bursts up within a forest of trees. It hovers above four flowing rivers - of paradise, a reference to medieval mapping. Or it runs, shadow-like, beneath them. These are markings of a projective imagination. They are tokens of Kimberley's efforts to think, visually, from a plangermairreener perspective. They begin to move toward their picturing of watery presence in their country, to showing how they might 'map' what is, to them, not a landscape. Kimberley pursues this goal in all of the paintings in the series: some come close to landscapes, others are conjunctions or overlays of entirely abstract forms. When joined to its companion painting, meenamatta water country, it becomes a diptych. It also becomes the summa of the series. The words inscribed across the surface, 'meenamatta walantanalinany', mean 'meenamatta country all round'.

For his part, Pura-lia Meenamatta writes prose poems that seek to grasp the same subject, in his own language, but also in English. He writes them directly on to the painting. The shapes float, as if they are floating on water, like leaves, but also in water, like continents. Reading around beyond the colonial construct: meenamatta map of unlandscape from top left to top right, down to the bottom left, then across to the lower right quadrant, these are the titles of each text: 'some call me water', 'this place is outside the bible', 'water', 'blue tears in manalargenna country', 'water spirits', 'in the time of living origin', 'birthing water', 'tubuna', 'antipodes', 'planegarrtoothenar', 'asia', 'africa', and 'europa'. As I noted above, they range in imaginative scope from precise locations in the poet's country to the evocations of movements outside of locative space and measurable time. Reversing Kimberley's approach, but matching it, they use English in ways that attempt to show plangermairreener perceptions about being-in-the-world to Western presumptions about space and time. They are Pura-lia Meenamatta's shot at locating his world views within those of the other.

For both artists, the point is to arrive at a state of connectivity between their separate ways of seeing what they take to be a shared world, one that is fully, but inadequately, described by each other's ways of world picturing. Each perspective is inadequate, because for it to be complete, it would necessarily exclude the other. Neither wishes this outcome. Nor is such an outcome generalisable any longer. Is there a larger perspective that can encompass both? If there is, it is not what is in front of us. beyond the colonial construct: meenamatta map of unlandscape may have gotten beyond the colonial construct, but it has got as far as showing us a meenamatta mode of mapping the nether space in which water moves, the nexus of actual terrain and mythic time-space for which the two artists use the word 'unlandscape'. Theirs is a deconstructive gesture, not as yet a constructive action. Perhaps this is why both painted and the textual surfaces read so flatly, why their evident thirst for depth and movement seems 
so stilled. Nevertheless, to get this far is no inconsiderable achievement. It may be, in contemporary conditions, as far as we can get. The artists understand their collaboration, their conversation, to be just beginning.

\section{Contemporary World Currents}

Like the geographers and mapmakers who precede them, most contemporary artists quite sensibly confine themselves to envisaging one or two aspects of what it is to world (taken as an active verb) in contemporary conditions. ${ }^{13}$ Taken altogether, however, worlding is an enterprise that is unfolding at world scale, something that, perhaps, art itself-or, more broadly, the human visual imagination - is undertaking. If this is so, what is precipitating it?

In my recent work I have developed a historical hypothesis about how-in the latter decades of the twentieth century-modern art became contemporary, or, more accurately stated, about how it happened that the variety of modern, modernist, traditional and indigenous visual arts being produced all over the world could no longer be positioned relative to some broad, all-encompassing narrative of art's historical development (such as modernism followed by postmodernism). For all of their evident differences (indeed, because the evidence of their difference was so intense) they became suddenly - in the first decade of the twenty-first century - simply coexistent, nakedly contemporaneous. It is this contemporaneity of difference that resonates throughout what we now see as contemporary art, as it does the expanded sense of worlds-within-the-World that constitutes our contemporary condition.

This is the sense in which I argue that a multi-faceted, highly differentiated shift from modern to contemporary art has occurred in distinct ways in the various art-producing centres and regions of the world. Many of us are involved in the enterprise of tracking these developments as they have unfolded in the localities and regions within which we work, and as they continue to do so. For example, John Clark's outstanding work as an empirical researcher, art historiographer and meta-theorist of these developments as they play out in Asia. ${ }^{14}$ There is increasing interest in how these new narratives connect with each other - in how localities relate to others in their region, in how regions relate to contingently

\footnotetext{
13 See Rosenberg, D. and Grafton, A. 2009, Cartographies of Time: A History of the Timeline, New York, Princeton Architectural Press; Chapter 7 reviews relevant artworks, as does Harmon, K. 2009, The Map as Art: Contemporary Artists Explore Cartography, New York, Princeton Architectural Press. I discuss a number of works of contemporary art that exemplify aspects of each layer, relationship and connection in part III of Smith, T. 2011, Contemporary Art: World Currents, London, Laurence King, where I examine themes such as world picturing, climate change and social media.

14 See, for example, Clark, J. 2010, Asian Modernities: Chinese and Thai Art Compared, 1980 to 1999, Sydney, Power Institute.
} 
connected others; and in how specific localities and regions relate to the various forms of internationalisation that were abroad during the modern period and that have arisen in response to our contemporaneity. This is a trafficking in artists, artworks, images and ideas; in institutional practices and cultural stereotypes; in models of differentiation, cooperation and reconciliation; in ways of seeing worlds, and the World as a whole - in short, in world-making in the visual arts within the context of being-in-the-world, the contemporary structure of which I have been attempting to sketch.

I will conclude by outlining briefly how I have tackled this subject in my book Contemporary Art: World Currents. Within the atomistic particularity of all of the art being made today, I discern three main currents, and within these various tendencies that vary from each other in different ways within each current. Overall, I try to grasp what is distinct within each current and tendency, what is shared between them, and what emerges in the specific connections that occur between them. The first prevails in what were the great metropolitan centres of modernity in Europe and the United States (as well as in societies and subcultures, such as Australia, closely related to them) and is a continuation of styles in the history of art, particularly Modernist ones. Remodernist, retrosensationalist and spectacularist tendencies, fusing into one current, continue to predominate in EuroAmerican and some other modernising art-worlds and markets, with widespread effect. The second has arisen from movements toward political and economic independence that occurred in former colonies and on the edges of Europe, and is thus shaped above all by clashing ideologies and experiences. The result is that artists prioritise both local and global issues as the urgent content of their work. It came into prominence on international circuits such as biennales and travelling temporary exhibitions - this is the art of transnational transitionality. Thirdly, the great increase in the number of artists world-wide, and the opportunities offered by new informational and communicative technologies to millions of users, has led to the viral spread of small-scale, interactive, d-i-y art (and art-like output) that is concerned less with high art style, or confrontational politics, more with explorations of temporality, place, affiliation and affect - the ever more uncertain conditions of contemporaneity on a fragile planet. Taken together, I suggest, these currents constitute the contemporary art of the late twentieth and early twenty-first centuries. World picturing is common to them all, but it is done in very different ways, and for different reasons. The contemporaneity of these differences is what makes today's art contemporary. 